Kunuz: Journal of Islamic Banking and Finance Vol. 1, No. 1 (2021): 35-43

\title{
FAKTOR-FAKTOR YANG MEMENGARUHI KEPUTUSAN NASABAH MENGGUNAKAN PEGADAIAN SYARIAH PADA CABANG PEGADAIAN SYARIAH (CPS) DATOE BINANGKANG
}

\author{
Nurul Fauziah Olii \\ Fakultas Ekonomi dan Bisnis Islam, Institut Agama Islam Negeri Manado \\ E-mail: nurulolii31@iain-manado.ac.id
}

\author{
Nasruddin Yusuf \\ Fakultas Syariah, Institut Agama Islam Negeri Manado \\ E-mail: nasruddin.yusuf@iain-manado.ac.id
}

\begin{abstract}
ABSTRAK
Nasabah dalam memutuskan pilihan terhadap lembaga keuangan, perlu mempertimbangkan beberapa faktor tertentu. Demikian halnya nasabah dalam menentukan untuk menggunakan layanan jasa seperti Pegadaian Syariah. Penelitian ini bertujuan untuk mengetahui faktor-faktor yang dapat memengaruhi keputusan nasabah menggunakan pegadaian syariah (CPS) Datoe Binangkang. Penelitian ini dilaksanakan di Kota Kotamobagu metode yang digunakan dalam penelitian ini adalah kualitatif. Metode pengumpulan data dilakukan dengan tiga cara yaitu observasi, wawancara, dokumentasi. Pegumpulan data dilakukan untuk memperoleh data di lapangan data tersebut selanjutnya dianalisis secara deskriptif kualitatif. Hasil penelitian ini menunjukkan bahwa dengan adanya kualitas pelayanan yang melebihi harapan nasabah yang dilakukan dan diterapkan pegadaian syariah dapat memenuhi keinginan serta kebutuhan nasabah demi tercapainya kepuasan pada nasabah itu sendiri. Hal tersebut akan membuat nasabah semakin percaya untuk menggunakan jasa pegadaian syariah, faktor lokasi yang mudah dicapai, adanya akses transportasi, tersedianya lahan parkir, lokasi yang strategi, adanya lokasi tenaga kerja, serta berdekatan dengan pusat perbelanjaan menjadi alasan utama nasabah dalam memilih. Demikian juag faktor promosi seperti media cetak, media sosial dan tatap muka sangat memengaruhi nasabah/masyarakat untuk menggunakan pegadaian syariah dalam melakukan segala macam transaksi secara terus menerus atau berulang, faktor religiusitas sangat memengaruhi keputusan nasabah/masyarakat dalam menggunakan pegadaian Syariah, karena dalam pegadaian Syariah sesuai dengan syariat Islam.
\end{abstract}

Kata Kunci: Datoe Binangkang; Keputusan nasabah; Pegadaian Syariah.

Faktor-Faktor Yang Mempengaruhi Keputusan Nasabah Menggunakan Pegadaian Syariah Cabang Pegadaian Syariah 


\section{PENDAHULUAN}

Seiring dengan berkembangnya aktivitas ekonomi, kebutuhan manusia terus berkembang. Begitu pula kebutuhan akan pendanaan untuk memenuhi kebutuhannya yang terus menerus menjadi bertambah. Kegiatan pinjam meminjam merupakan salah satu metode untuk memenuhi kebutuhan dana tersebut. aktivitas meminjam ini dilakukan oleh perseorangan atau badan hukum dengan sesuatu lembaga, baik lembaga keuangan informal maupun lembaga keuangan resmi.

Lembaga keuangan di Indonesia terdiri dari dua ialah, lembaga keuangan bank serta lembaga keuangan non bank. Kedua lembaga ini tidak hanya mempunyai fungsi selaku lembaga intermediasi pula mempunyai fungsi untuk menyalurkan dana kepada masyarakat serta senantiasa berupaya untuk membagikan pelayanan terbaik kepada masyarakat dalam bidang kredit (Khalik, 2016). Pegadaian ialah tempat untuk konsumen untuk meminjam uang dengan beberapa barang individu konsumen selaku jaminannya. Mengusung slogan "mengatasi masalah tanpa masalah". Dengan moto pegadaian diharapkan masyarakat tidak lagi berfikir dua kali untuk menggadaikan barang jaminan ataupun keperluan meminjam dana di pegadaian syariah (Idrus, 2018).

Lembaga resmi tersebut baik lembaga non bank saat ini masih terdapat kesan pada masyarakat kalau meminjam ke bank merupakan sesuatu yang lebih membanggakan dibanding dengan lembaga resmi/formal sementara itu dalam prosesnya tampaknya membutuhkan waktu yang relatif lama dengan persyaratan yang lumayan rumit dan jaminan yang memberatkan. Sementara itu pemerintah sudah memfasilitasi masyarakat dengan suatu indsutri Universal (perum) yang sudah mempraktikkan system pegadaian secara resmi ialah pegadaian persero yang menawarkan akses yang lebih gampang (Kartawidjaja, 2020).

Pegadaian ialah lembaga perkreditan dengan system gadai untuk pertamakalinya. Hadir di Indonesia pada abad ke-17 yang dibawa dan dikembangkan oleh maskapai perdagangan dari negera Belanda ialah V.O.C (Vereenigde Oost Indische Compagnie). Dalam rangka memperlancar aktifitas perekonomiannya, bertepatan pada tanggal 20 Agustus 1746 V.O.C lewat pesan keputusan Gubernur Jenderal Van Imhoff didirikanlah pegadain pegadaian yang bernama Bank Van Leening. Lembaga tersebut ialah lembaga kredit yang membagikan pinjaman uang kepada masyarakat dengan jaminan gadai. Semenjak itu, bentuk usaha pegadaian sudah mengalami beberapa kali perubahan sejalan dengan pergantian peraturan-peraturan yang mengaturnya.

Pegadaian mempunyai dua Unit usaha ialah unit usaha gadai konvensional serta unit gadai syariah. Mayoritas masyarakat Indonesia menganut agama Islam, oleh karena itu PT. Pegadaian (Persero) meluncurkan suatu produk gadai yang berbasiskan prinsip-prinsip syariah serta sesuai dengan hukum Islam. Perkembangan produk-produk keuangan berbasis syariah juga makin gempar serta mulai banyak yang diminati oleh masyarakat Indonesia, tidak terkecuali pegadaian. Semakin meningkat perkembangan produk-produk keuangan berbasis membuat

Faktor-Faktor Yang Mempengaruhi Keputusan Nasabah Menggunakan Pegadaian Syariah Cabang Pegadaian Syariah 36 
Kunuz: Journal of Islamic Banking and Finance Vol. 1, No. 1 (2021): 35-43 Website: http://ejournal.iain-manado.ac.id/index.php/kunuz

PT Pegadaian ikut serta dalam menyediakan produk-produk keuangan berbasis syariah. Pegadaian sendiri ialah lembaga keuangan yang menyalurkan pinjaman dengan dasar hukum gadai yang mempunyai tujuan untuk mencegah praktik pegadaian gelap, praktik riba dan pinjaman tidak wajar.(Randi, 2014)

Dengan diresmikannya Unit pegadaian Syariah, masyarakat mempunyai variasi pilihan lagi untuk mendapatkan tambahan dana secara cepat dengan prosedur yang gampang untuk dipenuhi kebutuhannya baik untuk konsumsi maupun usaha. Keberadaan Pegadaian Syariah semata-mata sebagai alternatif pilihan dari PT Pegadaian alternatif (Persero) untuk menawarkan jasa pinjaman dengan sistem gadai yang diharapkan bisa menggerakkan sektor rill dengan bermacam kepentingan nasabah tidak saja umat muslim, namun juga non muslim (Hadijah et al., 2015). Semakin maraknya perkembangan produk-produk berbasis syariah tidak menutup kemungkinan nasabah non muslim tertarik untuk menggadaikan barangnya secara mudah dan cepat untuk memperoleh dana di Pegadaian Syariah. Meskipun sebagian besar nasabah Pegadaian Syariah merupakan muslim tidak menutup kemungkinan Pegadaian Syariah mempunyai nasabah non muslim dengan membagikan data/informasi yang akurat, keuntungan dan nilai tambah yang akan diperoleh jika menjadi nasabah.

Tugas pokok dari lembaga pegadaian syariah yaitu memberikan pinjaman kepada masyarakat yang membutuhkan. Pemberian pinjaman ini tidak terbatas untuk golongan ataupun kelompok masyarakat tertentu, tetapi di Indonesia pemanfaatan lembaga keuangan masih didominasi oleh golongan menengah ke atas, serta masih sedikit menjangkau golongan menengah ke bawah. Fungsi operasi pegadaian syariah itu sendiri dijalankan oleh kantor-kantor Cabang Pegadaian Syariah/ULGS selaku unit organisasi di bawah binaan divisi usaha lain perum pegadaian. Tetapi, baru pada awal tahun 2004 Perum Pegadaian memisahkan pegadaian syariah ke dalam divisi tertentu ialah divisi usaha syariah dan menjadikan tiap cabangnya selaku binaan Kantor Wilayah (Kanwil) Perum Pegadaian. Tidak hanya itu, Perum Pegadaian juga sudah memiliki Dewan Pengawas Syariah (DPS) sendiri yang bermanfaat untuk memberikan pengarahan terhadap kehalalan produk yang diluncurkan.(Nurhisam, 2016)

Dalam upaya mengubah persepsi masyarakat, salah satu metode yang digunakan lembaga gadai adalah dengan menciptakan motto "menyelesaikan masalah tanpa masalah', Dengan terdapatnya motto tersebut diharapkan masyarakat tidak lagi segan ataupun ragu untuk datang ke pegadaian. Di Indonesia saat ini, terdapat dua jenis lembaga gadai yaitu pegadaian konvensional serta pegadaian syariah. Menurut Rais Implementasi operasi pegadaian syariah pada dasarnya nyaris sama dengan pegadaian konvensional. tetapi yang membedakan adalah pegadaian konvensional menerapkan sistem riba ataupun meminta biaya tambahan atas dana yang dipinjamkan, yang mana perihal ini tidak terdapat pada pegadaian syariah. Dalam pegadaian syariah yang diutamakan adalah bisa memberikan kemaslahatan sesuai dengan yang diharapkan masyarakat, dengan senantiasa menjauhkan praktik riba, qimar (spekulasi), ataupun Gharar 
Kunuz: Journal of Islamic Banking and Finance Vol. 1, No. 1 (2021): 35-43 Website: http://ejournal.iain-manado.ac.id/index.php/kunuz

(ketidakpastian), sehingga tidak berimplikasi pada terjadinya ketidakadilan serta kedzaliman pada masyarakat dan nasabah (Nasution, 2016).

Dalam memilih suatu lembaga keuangan, nasabah akan mempertimbangkan faktor-faktor tertentu sebelum memutuskan menggunakan layanan jasa Pegadaian Syariah. Terkait dengan keputusan nasabah untuk menggunakan jasa Pegadaian Syariah, faktor yang sangat mempengaruhi keputusan nasabah dalam memilih menggunakan Pegadaian Syariah adalah lokasi, promosi, kualitas pelayanan, dan alasan syariah. Faktor-faktor yang mempengaruhi perilaku nasabah terhadap keputusan pembelian menurut Kotler terdapat 4 P (Place, Price, Promotion, Product,) yang mempengaruhi terhadap keputusan pembelian (Kotler, 2013).

Di Kota Kotamobagu sendiri baru terdapat 3 unit pelayanan Pegadaian Syariah yaitu CPS Datoe Binangkang, UPS Al-Huda Kotamobagu dan UPS Pasar Serasi Kotamobagu. Dari ketiga pegadaian syariah tersebut peneliti lebih memilih pegadaian syariah Datoe Binangkang karena kualitas pelayanannya melebihi ekspektasi nasabah, serta lokasi yang strategis berada dipusat keramaian kota menjadi alasan nasabah lebih memilih pegadaian syariah, maka dari itu peneliti tertarik melakukan penelitian di Pegadaian Syariah CPS Datoe Binangkang. Pegadaian Syariah CPS Dotoe Binangkang berdiri dari tahun 2008 sampai dengan sekarang. Produk yang dikeluarkan oleh Pegadaian Syariah ini mempunyai karakteristik semacam, tidak menuntut bunga dalam berbagai bentuk karena riba, menetapkan uang sebagai alat tukar bukan sebagai komoditas yang diperdagangkan, serta keuntungannya diperoleh dari biaya jasa simpan barang yaitu memberlakukan biaya pemeliharaan dari benda atau barang yang digadaikan seperti yang telah diatur oleh Dewan Syariah Nasional. Yang menarik dari pegadaian Syariah yaitu prinsipnya dan telah disahkan oleh Dewan Pengawas Syariah pelayanan yang melebihi ekspektasi nasabah, perihal inilah yang jadi daya tarik dari Pegadaian Syariah guna menarik minat nasabah untuk menggunakan jasa layanan Pegadaian Syariah.

Dengan adanya pegadaian syariah maka dapat membantu memberantas praktik gadai gelap yang sangat memberatkan serta membebani masyarakat kalangan bawah. Alasan yang melatar belakangi diperbolehkannya berdirinya pegadaian syariah itu karena bersifat sosial, bisa membantu meringankan beban masyarakat menengah ke bawah yang dalam kesehariannya masih bersifat konsumtif, serta tujuannya pula untuk mewujudkan kemaslahatan untuk masyarakat.

\section{METODE PENELITIAN}

Penelitian ini merupakan penelitian lapangan yaitu pengamatan kualitatif. Metode ini sebagai metode ilmiah/scientific sebab sudah memenuhi kaidah-kaidah ilmiah yaitu konkrit/empiris, obyektif, terukur, rasional dan sistematis.

Penelitian ini menggunakan rumusan masalah asosiatif. Jenis penelitian asosiatif langsung keobjekannya guna memperoleh informasi atau data yang

Faktor-Faktor Yang Mempengaruhi Keputusan Nasabah Menggunakan Pegadaian Syariah Cabang Pegadaian Syariah 38 
relevan dengan pendek yaitu suatu rumusan masalah penelitian yang bersifat menanyakan hubungan antara dua-dua variabel ataupun lebih. Menurut Drajat Kuncoro penelitian ini bertujuan untuk menyelidiki kemungkinan sebab akibat yang ada dan mencari kembali aspek yang menjadi pemicu atau penyebab melalui data tertentu (Zalu, 2020).

Penelitian ini dilakukan pada nasabah Pegadaian Syariah CPS Datoe Binangkang khususnya masyarakat Kotamobagu yang bisa dijadikan sebagai sumber informasi dalam penelitian ini. Masyarakat yang dimaksud yaitu yang berdomisili asli Kotamobagu. Masyarakat Kota Kotamobagu merupakan sumber informan yaitu pemberi informasi tentang faktor-faktor yang mempengaruhi nasabah menggunakan pegadaian syariah yang diinginkan peneliti berkaitan dengan penelitian yang dilaksanakan.

Tempat penelitian dilaksanakan di Pegadaian Syariah CPS Datoe Binangkang. Populasi dalam penelitian ini yaitu seluruh nasabah yang menggunakan jasa Pegadaian Syariah CPS Datoe Binangkang. Informan yang hendak diwawancarai yaitu laki-laki dan perempuan masih dalam umur produktif yaitu antara umur 18-49 tahun.

Triangulasi data yaitu metode yang paling umum digunakan dalam penjaminan validitas data dalam penelitian kualitatif. Triangulasi merupakan pemeriksaan keabsahan data dengan memanfaatkan sesuatu yang lain di luar data itu untuk keperluan pengecekan data ataupun sebagai pembanding terhadap data itu.

Reduksi data berarti merangkum, memilih hal-hal yang pokok, memfokuskan pada hal-hal yang penting, dicari tema serta polanya. Sehingga data yang sudah direduksi akan memberikan gambaran yang lebih jelas serta memudahkan peneliti untuk melakukan pengumpulan data (Juliansyah, 2013).

Dalam pengumpulan data merupakan penarikan dari kesimpulan, peneliti harus paham dan tanggap terhadap sesuatu yang diteliti langsung di lapangan dengan menyusun pola-pola pengarahan dan sebab akibat (Sarip, 2015).

\section{HASIL DAN PEMBAHASAN}

Gadai adalah praktik transaksi keuangan yang telah lama dalam sejarah peradaban manusia. Sistem rumah gadai yang paling tua terdapat di Negara Cina pada 3.000 tahun yang silam, ada pula di Benua Eropa dan Kawasan Laut Tengah pada zaman Romawi dahulu. Tetapi di Indonesia, praktik gadai telah berumur ratusan tahun, yaitu masyarakat telah terbiasa melakukan transaksi utang-piutang dengan jaminan.

Dalam perjalanan Pegadaian mengalami beberapa kali perubahan status yaitu sebagai perusahaan Negara (PN) sejak 1 Januari 1961 kemudian berdasarkan Peraturan Pemerintah No.7 Tahun 1961 menjadi Perusahaan Jawatan, selanjutnya

Faktor-Faktor Yang Mempengaruhi Keputusan Nasabah Menggunakan Pegadaian Syariah Cabang Pegadaian Syariah 
berdasarkan peraturan Pemerintah Nomor 10 Tahun 1990 berganti menjadi perusahaan umum (PERUM). Sampai pada tahun 2011, bentuk badan hukum Pegadaian berubah jadi Perusahaan Perseroan (Persero). Sesuai Peraturan Pemerintah Nomor 51 yang diterbitkan pada 13 Desember 2011 lalu, status badan hukum Perum Pegadaian berubah jadi PT Pegadaian .(Erie Febrian, n.d.)

Secara makro, aspek kesejarahan pegadaian Syariah di Indonesia tidak bisa dipisahkan dari keinginan masyarakat Islam untuk melaksanakan transaksi gadai bersumber pada prinsip Syariah yang ditopang dengan adanya kebijakan Pemerintah untuk pengembangan praktik ekonomi serta lembaga-lembaga keuangan yang sesuai dengan nilai serta prinsip hukum Islam. Tidak hanya itu, semakin populernya praktik bisnis dan ekonomi Syariah dan memiliki peluang yang cerah untuk dikembangkan.

Data yang diperoleh di lapangan menunjukkan bahwa faktor-faktor yang memengaruhi keputusan nasabah dalam memilih pegadaian syariah sebagai berikut:

\section{Faktor kualitas pelayanan}

Kualitas pelayanan menurut Fandy Tjiptono, yang mendefinisikan sebagai keadaan dinamis yang erat kaitannya dengan sumber daya manusia, jasa serta produk, serta proses dan lingkungan yang setidaknya dapat memenuhi atau melebihi kualitas pelayanan yang diharapkan. Keinginan dari nasabah serta terpenuhinya kebutuhan dari nasabah itu sendiri merupakan nilai tambah di mata masyarakat/nasabah, dan juga ketepatan dan cara penyampaian dari karyawan dapat memenuhi harapan dan kepuasan pada nasabah.

Berdasarkan hasil temuan penelitian telah diperoleh data bahwa Faktor kualitas pelayanan pada pegadaian syariah Datoe Binangkang sangat memenuhi standar kualitas pelayanan yaitu dengan memberikan kenyamanan nasabah seperti ruang tunggu yang luas dan nyaman, kebersihan tempat, perilaku karyawan saat memberikan pelayanan ialah menunjukkan sopan santun serta keramahan ketika memberikan pelayanan.

Kualitas pelayanan yang baik yang diterapkan dan dilakukan pegadaian syariah dapat memenuhi keinginan serta kebutuhan nasabah demi tercapainya kepuasan pada nasabah itu sendiri. Seperti yang dikatakan oleh Herlianty Mokodompit, Mey Mongilong, Nandita Novia Linggasari, Arfandi Pontoh, dan Ayung bahwasanya pelayanan yang baik menjadi alasan penentu nasabah memilih suatu lembaga keuangan. Sejalan dengan teorinya Kotler bahwa pelayanan yang baik sangat berpengaruh terhadap keputusan pembelian. Kualitas layanan cenderung mempengaruhi keputusan menggunakan pegadaian syariah karena pelayanan yang melebihi ekspektasi dan dinilai baik akan di anggap sebagai kualitas layanan yang ideal. Hal tersebut akan membuat nasabah semakin yakin dan percaya untuk menggunakan jasa pegadaian syariah.

Faktor-Faktor Yang Mempengaruhi Keputusan Nasabah Menggunakan Pegadaian Syariah Cabang Pegadaian Syariah 40 


\section{Faktor Lokasi}

Dalam melakukan usaha lokasi memiliki peranan penting. Karena ada kaitannya dengan keramaian pusat kota dengan lokasi, lokasi tenaga kerja, gampang dijangkau dan tersedianya lahan parkir yang luas yang biasanya lebih disukai nasabah. Nasabah terlebih dahulu mempertimbangkan lokasi sebelum memutuskan membeli suatu produk. Sehingga lokasi dan keputusan nasabah ada kaitannya.

Pemilihan lokasi merupakan faktor bersaing yang penting dalam usaha menarik nasabah/masyarakat. Karena nasabah/masyarakat cenderung mempertimbangkan lokasi sebelum memilih. Pertimbangan-pertimbangan yang cermat dalam menentukan lokasi meliputi: (Susyanti et al., 2019)

a. Akses, misalnya lokasi yang dilalui atau mudah dijangkau sarana transportasi umum.

b. Visibilitas, misalnya lokasi dapat dilihat dengan jelas dari tepi jalan.

c. Tempat parkir yang luas dan aman.

d. Ekspansi, yaitu tersedia tempat yang luas untuk perluasan usaha dikemudian hari.

e. Lingkungan, yaitu daerah sekitar yang mendukung jasa yang ditawarkan. Misalnya warung makan yang berdekatan dengan daerah kos, asrama mahasiswa, atau perkantoran.

f. Persaingan yaitu lokasi pesaing. Misalnya dalam menentukan lokasi wartel perlu dipertimbangkan apakah di jalan atau di daerah yang sama, banyak pula terdapat wartel lain atau tidak.

\section{Faktor Promosi}

Pegadaian dalam memasarkan produknya perlu merancang serta menyebarkan informasi tentang ketersediaannya, kehadirannya, ciri-ciri produk dan kondisi produknya dan manfaat yang bisa diperoleh para nasabah/calon nasabah atas produk yang ditawarkan oleh pegadaian. Dengan adanya strategi promosi masyarakat dapat mengetahui produk apa saja yang ada. Seperti yang dikatakan oleh Putri Sahante, Dewi Djayanti Tabo, Aprilia Putri, Bayu Daeng Nompo, Jamila, Ferri, dan Magfira Ginoga bahwasanya lokasi sangat mempengaruhi keputusan nasabah dalam memilih lembaga keuangan. Sejalan dengan teorinya Muanas yakni faktor-faktor yang mempengaruhi perilaku terhadap keputusan nasabah dalam membeli sesuatu salah satunya faktor lokasi. Dan juga teori menurut Kotler kunci menuju kesuksesan salah satunya adalah lokasi.

\section{Faktor Religiusitas}

Dari hasil penelitian ditemukan bahwa kualitas keagamaan seseorang mempengaruhi keputusan dari nasabah untuk menggunakan pegadaian syariah Datoe Binangkang. Disamping itu latar belakang pendidikan seseorang menjadi pendorong terhadap pandangan masyarakat dalam menggunakan jasa pegadaian

Faktor-Faktor Yang Mempengaruhi Keputusan Nasabah Menggunakan Pegadaian Syariah Cabang Pegadaian Syariah 
Kunuz: Journal of Islamic Banking and Finance Vol. 1, No. 1 (2021): 35-43 Website: http://ejournal.iain-manado.ac.id/index.php/kunuz

syariah. Pendidikan seseorang akan menentukan wawasan orang tersebut, Sehingga mudah dalam menerima serta menyerap informasi mengenai pegadaian syariah.

\section{Faktor Keluarga}

Dari hasil temuan penelitian peneliti juga mendapatkan hasil temuan tambahan yaitu faktor keluarga. Dengan adanya saudara yang bekerja di pegadaian syariah membuat nasabah lebih memilih pegadaian syariah Datoe Binangkang. Dikarenakan jika ada keperluan atau urusan yang mendesak dapat langsung diatasi dengan bantuan saudara/karyawan yang bekerja di tempat tersebut.

Dengan demikian dengan adanya faktor kualitas pelayanan, lokasi, promosi, religiusitas, serta tambahan temuan faktor lain yang peneliti temukan yaitu faktor kekeluargaan merupakan alasan nasabah lebih memilih pegadaian syariah Datoe Binangkang untuk melakukan transaksi.

\section{KESIMPULAN}

Berdasarkan pada hasil penelitian dan pembahasan dalam "Faktor-faktor Yang Mempengaruhi Keputusan Nasabah Menggunakan Pegadaian Syariah (CPS) Datoe Binangkang', peneliti dapat menyimpulkan bahwa dengan adanya kualitas pelayanan yang melebihi harapan nasabah yang dilakukan dan diterapkan pegadaian syariah dapat memenuhi keinginan serta kebutuhan nasabah demi tercapainya kepuasan pada nasabah itu sendiri. Hal tersebut akan membuat nasabah semakin percaya untuk menggunakan jasa pegadaian syariah, faktor lokasi yang mudah dicapai, adanya akses transportasi, tersedianya lahan parkir, lokasi yang strategi, adanya lokasi tenaga kerja, serta berdekatan dengan pusat perbelanjaan menjadi alasan utama nasabah dalam memilih, faktor promosi seperti media cetak, media sosial dan tatap muka sangat mempengaruhi nasabah/masyarakat untuk menggunakan pegadaian syariah dalam melakukan segala macam transaksi secara terus menerus atau berulang, faktor religiusitas sangat mempengaruhi keputusan nasabah/masyarakat dalam menggunakan pegadaian syariah, karena dalam pegadaian syariah sesuai dengan syariat Islam. Serta terdapat tambahan yaitu faktor keluarga. Dengan adanya saudara yang bekerja di pegadaian syariah membuat nasabah lebih memilih pegadaian syariah Datoe Binangkang. Dikarenakan jika ada keperluan atau urusan yang mendesak dapat langsung diatasi dengan bantuan saudara/karyawan yang bekerja di tempat tersebut.

\section{DAFTAR PUSTAKA}

Erie Febrian. (n.d.). Potensi dan Preferensi terhadap Perilaku Memilih Pegadaian Syariah, $h .8$.

Hadijah, S., Zukhri, A., \& Suwena, K. R. (2015). Faktor-faktor yang Mempengaruhi Keputusan Nasabah Menggunakan Jasa Pegadaian Syariah Kantor Cabang Pegadaian Syariah (KCPS) Denpasar. Jurnal Pendidikan Ekonomi Undiksha, 5(1).

Faktor-Faktor Yang Mempengaruhi Keputusan Nasabah Menggunakan Pegadaian Syariah Cabang Pegadaian Syariah 42 
Kunuz: Journal of Islamic Banking and Finance Vol. 1, No. 1 (2021): 35-43 Website: http://ejournal.iain-manado.ac.id/index.php/kunuz

Idrus, T. (2018). Faktor-Faktor yang Mempengaruhi Keputusan Nasabah dalam Memilih Produk Rahn di Pegadaian Syariah Ar Hakim Medan dengan Cabang Metode Borda, h. 52.

Juliansyah, E. (2013). Metode Penelitian. Metode Penelitian, 37-54.

Kartawidjaja, J. (2020). Persepsi Masyarakat Terhadap Semboyan Pegadaian Syariah Mengatasi Masalah Tanpa Masalah Dalam Menarik Minat Gadai Masyarakat Desa Sepit, Kec. Keruak, Kab. Lombok Timur. 21(1), 1-9.

Khalik, A. (2016). Pengaruh Loan To DepositT Ratio Terhadap Profitabilitas Pada PT Bank Rakyat Indonesia (Persero) Tbk Cabang Makassar Ahmad Yani. AKMEN Jurnal Ilmiah, 13(4).

Kotler. (2013). Bauran Pemasaran. 53(9), 1689-1699.

Nasution, R. S. (2016). Sistem Operasional Pegadaian Syariah Berdasarkan Surah Al-Baqarah 283 pada PT. Pegadaian (Persero) Cabang Syariah Gunung Sari Balikpapan. Al-Tijary, 1(2), 93-119.

Nurhisam, L. (2016). Kepatuhan Syariah Dalam Industri Keuangan Syariah. Jurnal Hukum IUS QUIA IUSTUM, 23(1), 77-96.

Randi, S. (2014). Pegadaian Syariah Di Kota Medan. Jurnal Ekonomi Dan Keuangan, 2(4), 221-235.

Sarip, H. (2015). Penarikan Reduksi Data, h. 15. 1-16.

Susyanti, J., ABS, M. K., \& others. (2019). Analisis Pengaruh Tingkat Religiusitas, Pengetahuan Dan Lingkungan Sosial Terhadap Minat Menabung Mahasiswa Di Bank Syariah Kota Malang (Studi Kasus Pada Mahasiswa Banyuwangi Di Kota Malang). Jurnal Ilmiah Riset Manajemen, 8(19).

Zalu, S. (2020). Strategi Penelitian Kualitatif dan Kuantitatif, h. 38. Jurnal, 4, 2838 .

Faktor-Faktor Yang Mempengaruhi Keputusan Nasabah Menggunakan Pegadaian Syariah Cabang Pegadaian Syariah 